\title{
Assessment of relationship between serum magnesium and serum glucose levels and HOMA-IR in diabetic and prediabetic patients
}

\section{Diyabetik ve prediabetik hastalarda serum magnezyum ve serum glukoz düzeyleri ile HOMA-IR arasındaki ilişkinin değerlendirilmesi}

\author{
Gülçin Şahingöz Erdal ${ }^{1}$, Faruk Karandere ${ }^{1}$, Fuat Mısıroğlu ${ }^{1}$, Işıl Özbaş Tevetoğlu ${ }^{1}$, Yıldız Okuturlar ${ }^{2}$, \\ Hakan Koçoğlu ${ }^{1}$, Mehmet Hurşitoğlu ${ }^{1}$
}

\begin{abstract}
Aim: In this study, we aimed to investigate the serum magnesium $(\mathrm{Mg})$ levels in diabetic and prediabetic patients and its correlation with age, body-mass index, HOMA-IR, serum fasting glucose, HbA1c, and insulin levels.

Methods: In this retrospective study, a total of 130 patients consisted of newly diagnosed prediabetes (Group PD) ( $n=63$ ) and type 2 diabetes mellitus (Group D) $(n=67)$ were included. Patients' age, body mass index, serum $\mathrm{Mg}$, glucose and insulin, HOMA-IR and HbAlc were recorded. The prediabetes and type 2 diabetes diagnoses had been made according to WHO criteria at the time of diagnosis.

Results: In group D, the mean Mg level $(1.88 \pm 0.17 \mathrm{mg} / \mathrm{dl})$ was significantly lower than group PD $(1.96 \pm 0.17$ $\mathrm{mg} / \mathrm{dl})(\mathrm{p}=0.007)$. Correlation analysis showed that there was a significant negative correlation between $\mathrm{Mg}$ and glucose $(r=-0.390, p=0.001)$ and HOMA-IR $(r=-0.284 ; p=0.022)$ in the group D. No correlation was found between serum $\mathrm{Mg}$ level and serum insulin, $\mathrm{HbAlc}$, age, and body-mass index ( $\mathrm{p}=0.801,0.087,0.611$ and 0.691 , respectively). In group PD, serum insulin, HbA1c, glucose, HOMA-IR, age, and body-mass index were not corraleted with serum Mg levels ( $\mathrm{p}=0.801,0.087,0.939,0.998,0.611$ and 0.691 , respectively).

Conclusion: We showed that while there was a negative correlation between magnesium levels and HOMA-IR and fasting blood glucose levels in diabetic patients, but this correlation was not present in prediabetic patients. Our results suggest that serum $\mathrm{Mg}$ level is associated with metabolic control of type 2 diabetes and thus it can be considered in these patients.
\end{abstract}

Key words: Magnesium, diabetes, prediabetes, insülin resistance, fasting glucose, HOMA-IR

Öz

Amaç: Bu çalışmada diyabetik ve prediyabetik hastalarda serum magnezyum $(\mathrm{Mg})$ düzeyleri ile yaş, vücut kitle indeksi, HOMA-IR, serum açlık glukoz, HbA1c ve insülin düzeyleri arasındaki ilişkiyi inceledik.

Yöntemler: Bu retrospektif çalışmada, yeni tanı almış prediyabet (Grup PD) (n=63) ve tip 2 diabetes mellitus (Grup D) ( $\mathrm{n}=67$ ) olmak üzere toplam 130 hasta çalışmaya alındı. Hastaların yaşı, vücut kitle indeksi, serum $\mathrm{Mg}$, glukoz ve insülin değerleri, HOMA-IR ve HbA1c kaydedildi. Prediabetes ve tip 2 diyabet tanısı, tanı anında WHO kriterlerine göre yapıldı.

Bulgular: Grup D'de ortalama Mg düzeyi (1,88 $\pm 0,17 \mathrm{mg} / \mathrm{dl})$, grup PD'den $(1,96 \pm 0,17 \mathrm{mg} / \mathrm{dl})$ anlamlı derecede düşüktü $(p=0,007)$. Korelasyon analizi, D grubunda $\mathrm{Mg}$ ve glukoz $(r=-0,390, p=0,001)$ ve HOMA-IR $(r=$ $0,284 ; p=0,022)$ arasında anlamlı negatif korelasyon olduğunu gösterdi. Serum $\mathrm{Mg}$ ile insülin, $\mathrm{HbA1c}$, yaş ve vücut kütle indeksi (sırasıyla $\mathrm{p}=0,801,0,087,0,611$ ve 0,691 ) arasında korelasyon saptanmadı. Grup PD'de serum insülin, HbAlc, glukoz, HOMA-IR, yaş ve vücut kitle indeksi ile serum Mg düzeyleri arasında korelasyon yoktu (sırasiyla $\mathrm{p}=0,801,0,087,0,939,0,998,0,611$ ve 0,691 ).

Sonuçlar: Diyabetik hastalarda magnezyum düzeyleri ile HOMA-IR ve açlık kan glikoz düzeyleri arasında negatif bir ilişki olduğunu, ancak bu ilişkinin prediyabetik hastalarda mevcut olmadığını gösterdik. Çalışma sonuçlarımız serum $\mathrm{Mg}$ seviyesinin tip 2 diyabetin metabolik kontrolü ile ilişkili olduğunu ve bu nedenle bu hastalarda göz önüne alınabileceğini düşündürmektedir.

Anahtar Kelimeler: Magnezyum, diyabet, prediyabet, insülin direnci, açlık glikoz, HOMA-IR
1 Bakirkoy Dr. Sadi Konuk Education and Research Hospital, Department of Internal Medicine, Istanbul, Turkey

2 Acibadem Mehmet Ali Aydinlar University, Atakent Education and Research Hospital, Department of Internal Medicine, Istanbul, Turkey

Ethics Committee Approval: The study wass approved by the local ethical authority

Etik Kurul Onayı: Çalışma lokal etik komite tarafindan onaylanmıştır.

Conflict of Interest: No conflict of interest was declared by the authors.

Çıkar Çatışması: Yazarlar çıkar çatışması bildirmemişlerdir.

Financial Disclosure: The authors declared that this study has received no financial support. Finansal Destek: Yazarlar bu çalıșma için finansal destek almadıklarını beyan etmişlerdir.

Geliş Tarihi / Received: 08.08.2018 Kabul Tarihi / Accepted: 11.12.2018

Yayın Tarihi / Published: 15.03.2019

Sorumlu yazar / Corresponding author: Gülçin Şahingöz Erdal

Department of Internal Medicine, Bakirkoy Dr. Sadi Konuk Education and Research Hospital, Istanbul, Turkey

e-posta: gulcinctf@hotmail.com

Tel/Phone: +90531 6427516

Copyright $(\subset$ ACEM 


\section{Introduction}

Magnesium (Mg) is the second most abundant intracellular cation after potassium present in living cells and may influence the regulation of blood glucose metabolism by modulation of insulin secretion and insulin action [1]. Therefore, alterations in the metabolism of this mineral may influence these functions, contributing to the pathogenesis of obesity and insulin resistance $[2,3]$.

Studies and knowledge on the relationship between diabetes and $\mathrm{Mg}$ status are expanding. Hypomagnesemia is a common finding in type 2 diabetic patients (T2DM) [4]. It has been reported to occur in 13.5 to $47.7 \%$ of patients with T2DM compared with 2.5 to $15 \%$ among their counterparts without diabetes [5-8]. Some studies have demonstrated the action of $\mathrm{Mg}$ on insulin resistance in obesity and diabetes, and thus $\mathrm{Mg}$ deficiency has been proposed as a risk factor for T2DM [1, 9, $10]$.

Prediabetes, characterized by impaired fasting glucose and/or impaired glucose tolerance, is considered an important risk factor for the development of overt diabetes [11]. A few studies have investigated the association of serum $\mathrm{Mg}$ levels with prediabetes, but the findings were inconsistent $[3,12]$

In this study, we have aimed to investigate the serum $\mathrm{Mg}$ levels in patients with T2DM and prediabetes and its correlation with serum fasting glucose, insulin, HOMA-IR (Homeostatic Model Assessment for Insulin Resistance) and HbA1c levels.

\section{Material and methods}

In this retrospective study, patients with newly diagnosed prediabetes and T2DM who were admitted to Diabetes and Internal Medicine outpatient clinics of Bakirkoy Dr. Sadi Konuk Education and Research Hospital between February 2017 and January 2018 were evaluated. The study was approved by institutional ethical committee of the Bakirkoy Dr. Sadi Konuk Education and Research Hospital (2018/144), which complies with Helsinki Declaration.

A total of 130 patients with prediabetes and T2DM were included in this study. The study included 67 newly diagnosed T2DM (group D) and 63 newly diagnosed prediabetic patients (group PD). All patients were newly diagnosed patients and have not reported a history of diabetes and not used insulin or an oral antidiabetic agent at the time of diagnosis. At our outpatient clinics the prediabetes and T2DM diagnoses have been made according to WHO criteria [13].

Exclusion criterias were as follows: patients other than newly diagnosed diabetes and/or prediabetes; patients with hypertension, chronic renal failure, acute or chronic diarrhea, malabsorption syndrome, congenital diseases, immunologic diseases, acute/chronic pancreatitis, cirrhosis, malignancy, epilepsy and patients who were using alcohol, magnesiumcontaining antacids, magnesium-containing vitamin-mineral preparations.

Patients' age, weight, height, glucose, insulin, HOMAIR, glycosylated hemoglobin (HbA1c), calcium (Ca), Mg, and 25 $(\mathrm{OH})$ vitamin-D levels were recorded. Body mass indexes (BMI) [(weight $(\mathrm{kg}) /$ height $\left.\left(\mathrm{m}^{2}\right)\right]$ of all patients were calculated using height and weight measurements. HOMA-IR was measured to determine insulin resistance and calculated as the fasting insulin level $(\mu \mathrm{U} / \mathrm{mL}) \times$ early morning fasting blood glucose level $(\mathrm{mg} / \mathrm{dL}) / 405$. In our clinical routine, blood samples were taken in the morning after at least 12 hours of nightly fasting.
For the statistical analysis, SPSS version 17 for Windows (Statistical Package for Social Sciences - SPSS, Chicago, IL, USA) was used. Student $t$ test was used for comparison of descriptive statistical methods (mean and standard deviation) as well as quantitative data when study data were evaluated. Pearson correlation test was used when the relations between the parameters were examined. Chi-square test was used for comparison of qualitative data. The results were evaluated in a confidence interval of $95 \%$ and a significance level of $\mathrm{p}<0.05$.

\section{Results}

This study included 130 patients consisted of 67 newly diagnosed T2DM (group D) and 63 newly diagnosed prediabetic (group PD) patients. There was no statistically significant difference in mean age between the group D (44.89 \pm 7.67 years) and group PD $(42.14 \pm 8.74$ years $)(p=0.058)$ patients. Only $7.7 \%$ $(\mathrm{n}=10)$ of our study population was over 55 years of age.

Descriptive data of groups D and PD is shown in Table 1. In group $\mathrm{D}$, the mean $\mathrm{Mg}$ level $(1.88 \pm 0.17 \mathrm{mg} / \mathrm{dL})$ was significantly lower than group PD $(1.96 \pm 0.17 \mathrm{mg} / \mathrm{dL})(\mathrm{p}=0.007)$. Also, in group D, serum glucose, HOMA-IR and HbA1c levels were found to be statistically higher than group PD whereas BMI and magnesium levels in the group PD were found to be statistically higher than group D (Table 1).

Table 1. Descriptive data of diabetic and prediabetic patients and comparison between the groups.

\begin{tabular}{lccc} 
& Group PD $(\mathrm{n}=63)^{¥}$ & Group D $(\mathrm{n}=67)^{¥}$ & $\mathrm{p}$ \\
\hline Age $(\mathrm{year})$ & $42.14 \pm 8.74$ & $44.89 \pm 7.67$ & 0.058 \\
BMI $\left(\mathrm{kg} / \mathrm{m}^{2}\right)$ & $34.41 \pm 6.46$ & $28.77 \pm 5.21$ & 0.0001 \\
Glucose $(\mathrm{mg} / \mathrm{dl})$ & $96.22 \pm 10.01$ & $191.16 \pm 81.67$ & 0.0001 \\
Insulin $(\mu \mathrm{u} / \mathrm{ml})$ & $14.95 \pm 6.50$ & $15.60 \pm 16.64$ & 0.205 \\
HOMA-IR score & $3.57 \pm 1.61$ & $7.22 \pm 9.22$ & 0.001 \\
HbA1c $(\%)$ & $5.70 \pm 0.40$ & $8.40 \pm 2.46$ & 0.0001 \\
$\mathrm{Ca}(\mathrm{mg} / \mathrm{dl})$ & $9.62 \pm 0.46$ & $9.43 \pm 0.42$ & 0.012 \\
Mg $(\mathrm{mg} / \mathrm{dl})$ & $1.96 \pm 0.17$ & $1.88 \pm 0.17$ & 0.007 \\
Vitamin D $(\mathrm{ng} / \mathrm{ml})$ & $16.11 \pm 11.36$ & $19.57 \pm 10.77$ & 0.088 \\
\hline
\end{tabular}

$¥:$ Mean \pm standard deviation, BMI: Body mass index, HOMA-IR: Homeostatic Model Assessment - Insulin Resistance, Ca: Calcium, Mg: Magnesium, HbA1c: Glycosylated hemoglobin

Significant negative correlations were found between $\mathrm{Mg}$ and glucose levels $(\mathrm{r}=-0.390 ; \mathrm{p}=0.001)$ and HOMA-IR values $(r=-0.284 ; p=0.022)$ in group $D$, but the same correlations were not found in group PD. Also, age, BMI and serum insulin levels were not correlated with serum $\mathrm{Mg}$ levels in both groups (Table 2).

Table 2. Correlation analysis between Mg level and BMI, blood glucose, insulin, and $\mathrm{HbA} 1 \mathrm{c}$ levels.

\begin{tabular}{lcccc}
\multirow{2}{*}{ Magnesium } & \multicolumn{2}{c}{ Prediabetes } & \multicolumn{2}{c}{ Diabetes } \\
\cline { 2 - 5 } & $\mathrm{r}$ & $\mathrm{p}$ & $\mathrm{r}$ & $\mathrm{p}$ \\
\hline Age $(\mathrm{year})$ & 0.065 & 0.611 & 0.083 & 0.506 \\
BMI $\left(\mathrm{kg} / \mathrm{m}^{2}\right)$ & -0.051 & 0.691 & -0.031 & 0.809 \\
Glucose $(\mathrm{mg} / \mathrm{dl})$ & 0.01 & 0.939 & -0.390 & 0.001 \\
Insulin $(\mu \mathrm{u} / \mathrm{ml})$ & -0.032 & 0.801 & -0.108 & 0.393 \\
HOMA-IR score & 0.000 & 0.998 & -0.284 & 0.022 \\
HbA1c $(\%)$ & 0.217 & 0.087 & -0.240 & 0.051 \\
\hline
\end{tabular}

BMI: Body mass index, HOMA-IR; Homeostatic Model Assessment Insulin Resistance, HbA1c: Glycosylated hemoglobin

\section{Discussion}

This study shows the effect of serum magnesium levels on serum glucose and HOMA-IR values in T2DM patients which could have an impact on diabetes regulation in those patients in clinical routine. 
Electrolyte disorders are common in diabetic patients and closely related to increased morbidity and mortality. In a study, a total of 5179 patients over 55 years old have been evaluated for electrolyte disturbance and at least one electrolyte imbalance has been observed in 776 cases (15\%) [14]. Electrolyte imbalance is more commonly seen in patients with poor blood glucose regulation and those with renal dysfunction $[8,15]$. In our study, patients with renal dysfunction were excluded from the study in order to exclude any conflict.

One of the common electrolyte disorders among diabetic patients is hypomagnesaemia. In a study published in 2004 in United States [16], in which participants who were consisted of 40,000 women aged 45 years and older, 918 subjects had diabetes mellitus and lower magnesium levels than nondiabetic subjects. Similar results have also been obtained in another study [14] aiming to determine the frequency of electrolytic impairment in the elderly population in 2013. Analysis of that study has shown that diabetes was an independent risk factor for hypomagnesaemia in people aged 55 years or older. A study by Odusan et al. [17] has shown that diabetic patients had a lower magnesium level than nondiabetics. In that study, about one-quarter of diabetic patients had hypomagnesemia. In our study, we have determined a significant negative correlation between serum magnesium and glucose level in diabetic patients but there was no correlation in prediabetic patients. However, we could not find a significant relationship between $\mathrm{Mg}$ level and age in our study. Similar result was found in the study by Arpaci et al. [18]. This could be caused from the younger age of the patient population taken into the our study.

Studies conducted by Dasgupta et al. [19] and GuerroRomero et al. [20] have shown that hypomagnesemia increases the risk of complications in diabetic patients, affects glucose regulation badly. A study published in 2018 [21] has been suggested that magnesium might be important because of the antioxidant effect in providing metabolic control of type 2 diabetes. Reasons for the frequent occurrence of hypomagnesemia in diabetics include inappropriate magnesiumuria, incomplete magnesium intake, glomerular hyperfiltration, impaired insulin metabolism, diuretic usage, and recurrent metabolic acidosis [22, 23]. In our study, we have excluded the patients who were using any anti-hypertensive drugs and also patients with renal dysfunction. However, we did not determine the urinary $\mathrm{Mg}$ levels in our patients. And we also did not calculate the levels of eGFR (glomerular filtration rate) in our patients. In terms of metabolic acidosis, having a history of diabetes including diabetic ketoacidosis was also an exclusion criterion of our study. We found a significant negative correlation between Mg level and HOMA-IR values in diabetic patients but no correlation was found in prediabetic patients.

The detection and correction of altered $\mathrm{Mg}$ status in diabetic patients is clinically appropriate, although many physicians tend to ignore $\mathrm{Mg}$ status. The increased risk of developing impaired glucose tolerance and/or frank DM2 in persons with dietary or serum $\mathrm{Mg}$ deficits have suggested a potential benefit of $\mathrm{Mg}$ supplements in patients with DM2 or in the presence of risk factors for DM2. Mg supplements have been proposed as a complementary tool for the prevention of DM2 and its metabolic control [1].

T2DM is a condition in which the electrolyte disorders are frequently seen due to the pathophysiology of the disease as well as the drugs used and comorbid conditions. It is important to evaluate the electrolytes and to take measures to correct this condition if any disorder is detected [24]. Some benefits of $\mathrm{Mg}$ supplements on glycemic profiles have been found in most but not all studies. In our study, we showed a significant negative correlation between magnesium levels and HOMA-IR and fasting blood glucose levels in diabetic patients, but this correlation did not exist in prediabetic ones. Our study included newly diagnosed patients in order to avoid a possible interference between our results and 'disease other than diabetesrelated' or drug-related $\mathrm{Mg}$ disturbance. As we did not investigate the effect of magnesium on diabetes regulation, we could not evaluate the clinical efficacy of magnesium replacement on T2DM patients.

In conclusion, our study results suggest that serum $\mathrm{Mg}$ level is associated with metabolic control of T2DM, and thus it can be considered in T2DM patients.

\section{References}

1. Barbagallo M. Magnesium and type 2 diabetes. World J Diabetes. 2015;6:1152-7.

2. Jahnen-Dechent W, Ketteler M. Magnesium basics. Clin Kidney J. 2012;5:i3-i14.

3. Simmons D, Joshi S, Shaw J. Hypomagnesaemia is associated with diabetes: Not pre-diabetes, obesity or the metabolic syndrome. Diabetes Res Clin Pract. 2010;87:261-6.

4. Ma J, Folsom AR, Melnick SL, Eckfeldt JH, Sharrett AR, Nabulsi AA, et al. Associations of serum and dietary magnesium with cardiovascular disease, hypertension, diabetes, insulin, and carotid arterial wall thickness: the ARIC study. Atherosclerosis Risk in Communities Study. J Clin Epidemiol. 1995;48:927-40.

5. Pham PC, Pham PM, Pham PA, Pham SV, Pham HV, Miller JM, et al. Lower serum magnesium levels are associated with more rapid decline of renal function in patients with diabetes mellitus type 2. Clin Nephrol. 2005;63:429-36.

6. Mather HM, Nisbet JA, Burton GH, Poston GJ, Bland JM, Bailey PA, et al. Hypomagnesaemia in diabetes. Clin Chim Acta. 1979;95:235-42.

7. de Lordes Lima M, Cruz T, Pousada JC, Rodrigues LE, Barbosa K, Cangucu V. The effect of magnesium supplementation in increasing doses on the control of type 2 diabetes. Diabetes Care. 1998;21:682-6.

8. Walti MK, Zimmermann MB, Spinas GA, Hurrell RF. Low plasma magnesium in type 2 diabetes. Swiss Med Wkly. 2003;133:289-92.

9. Mooren FC. Magnesium and disturbances in carbohydrate metabolism. Diabetes Obes Metab. 2015;17:813-23.

10. Tosiello L. Hypomagnesemia and diabetes mellitus. A review of clinical implications. Arch Intern Med. 1996;156:1143-8.

11. Nichols GA, Hillier TA, Brown JB. Progression From Newly Acquired Impaired Fasting Glusose to Type 2 Diabetes. Diabetes Care. 2007;30:228-33.

12. Fang C, Wang X, Wu W, Gu X, Ye T, Deng H, et al. Association of Serum Magnesium Level with Odds of Prediabetes and Diabetes in a Southern Chinese Population: a Prospective Nested Case-Control Study. Biol Trace Elem Res. 2015;172:307-14.

13. World Health Organization. Definition and diagnosis of diabetes mellitus and intermediate hyperglycemia - Report of a WHO/IDF Consultation: WHO Press, World Health Organization, Geneva, Switzerland 2006 [cited 2018 June, 1st]. Available from: http://www.who.int/diabetes/publications/Definition and diagnosis of diabetes_new.pdf.

14. Liamis G, Rodenburg EM, Hofman A, Zietse R, Stricker BH, Hoorn EJ Electrolyte disorders in community subjects: prevalence and risk factors. Am J Med. 2013;126:256-63.

15. Palmer BF, Clegg DJ. Electrolyte and Acid-Base Disturbances in Patients with Diabetes Mellitus. N Engl J Med. 2015;373:548-59.

16. Song Y, Manson JE, Buring JE, Liu S. Dietary magnesium intake in relation to plasma insulin levels and risk of type 2 diabetes in women. Diabetes Care. 2004;27:59-65.

17. Odusan OO, Familoni OB, Odewabi AO, Idowu AO, Adekolade AS Patterns and Correlates of Serum Magnesium Levels in Subsets of Type 2 Diabetes Mellitus Patients in Nigeria. Indian J Endocrinol Metab. 2017;21:439-42.

18. Arpaci D, Tocoglu AG, Ergenc H, Korkmaz S, Ucar A, Tamer A. Associations of serum Magnesium levels with diabetes mellitus and diabetic complications. Hippokratia. 2015;19:153-7.

19. Dasgupta A, Sarma D, Saikia UK. Hypomagnesemia in type 2 diabetes mellitus. Indian J Endocrinol Metab. 2012;16:1000-3.

20. Guerrero-Romero F, Simental-Mendia LE, Hernandez-Ronquillo G, Rodriguez-Moran M. Oral magnesium supplementation improves glycaemic status in subjects with prediabetes and hypomagnesaemia: A 
double-blind placebo-controlled randomized trial. Diabetes Metab. 2015;41:202-7.

21. Morakinyo AO, Samuel TA, Adekunbi DA. Magnesium upregulates insulin receptor and glucose transporter-4 in streptozotocinnicotinamide-induced type-2 diabetic rats. Endocr Regul. 2018;52:6-16.

22. Liamis G, Liberopoulos E, Barkas F, Elisaf M. Diabetes mellitus and electrolyte disorders. World J Clin Cases. 2014;2:488-96.

23. Pham PC, Pham PM, Pham SV, Miller JM, Pham PT. Hypomagnesemia in patients with type 2 diabetes. Clin J Am Soc Nephrol. 2007;2:366-73.

24. Özsan M, Yaprak M, Özcan O, Kiriktir E, Turgut F. Tip 2 Diyabetli Hastalarda Elektrolit Bozuklukları. Turkish Nephrology Dialysis Transplantation. 2017;26:285-9. 